\title{
PENGARUH PENGGUNAAN INTERNET TERHADAP KENAKALAN REMAJA (SISWA)
}

\author{
Oleh: \\ Asniati $^{1)}$, Sudarmi Suud B ${ }^{2)}$, Jahada $^{3)}$ \\ 1) 2) 3) Jurusan Bimbingan dan Konseling \\ Fakultas Keguruan dan Ilmu Pendidikan, Universitas Halu Oleo \\ Email: asniaty.sweet@yahoo.co.id
}

\begin{abstract}
ABSTRAK
Tujuan penelitian adalah untuk mendeskripsikan dan menganalisis pengaruh penggunaan internet terhadap kenakalan remaja (siswa) SMA Negeri 2 Tomia. Penelitian ini bersifat expost facto yang bertujuan untuk mencari informasi tentang hubungan sebab akibat dari suatu peristiwa. Populasi dalam penelitian ini adalah seluruh siswa kelas XI IPS SMA Negeri 2 Tomia yang terbagi 4 kelas yang berjumlah 125 orang sedangkan sampel penelitian sebanyak 32 orang yang diambil dengan menggunakan teknik purposive sampling. Teknik pengumpulan data yang digunakan dalam penelitian ini adalah angket yaitu angket penggunaan internet dan kenakalan remaja siswa. Dari hasil analisis data yaitu analisis regresi dapat disimpulkan bahwa ada pengaruh yang signifikan penggunaan internet siswa terhadap kenakalan remaja SMA Negeri 2 Tomia. Hal ini menunjukan bahwa semakin tinggi penggunaan internet maka semakin tinggi pula kenakalan remaja siswa di SMA Negeri 2 Tomia Kabupaten Wakatobi. Besarnya kontribusi penggunaan internet terhadap kenakalan remaja siswa di SMA Negeri 2 Tomia adalah sebesar 32,8\%.
\end{abstract}

Kata Kunci: Penggunaan Internet, Kenakalan Remaja

\section{THE EFFECT OF INTERNET USAGE AGAINST JUVENILE DELINQUENCY (STUDENTS) SMA NEGERI 2 TOMIA}

\begin{abstract}
The purpose of this research is to describe and analyze the influence of internet misuse to juvenile delinquency (student) of SMA Negeri 2 Tomia. This research is an expost facto that aims to find information about the cause and effect relationship of an event. The population in this study were all students of class XI IPS of SMA Negeri 2 Tomia divided into 4 classes which amounted to 125 people while the sample of the study were 32 people taken by using purposive sampling technique. Data collection techniques used in this study is a questionnaire that is the questionnaire of internet use and juvenile delinquency of students. Data collection techniques used in this study is a questionnaire that is the questionnaire of internet use and juvenile delinquency of students. Data analysis techniques in this study using descriptive statistical analysis techniques and inferential analysis. Descriptive statistical analysis is used to describe data while inferential analysis is used to analyze the influence of internet usage and juvenile delinquency of students by using SPSS application. From the results of data analysis regression analysis can be concluded that there is a significant influence of internet use of students against juvenile delinquency SMA Negeri 2 Tomia showed that the higher the negative use of the internet the higher the juvenile delinquency of students in SMA Negeri 2 Tomia Wakatobi District. The amount of contribution of internet use to juvenile delinquency of student in SMA Negeri 2 Tomia is $32,8 \%$.
\end{abstract}

Keywords: Internet Use, Juvenile Delinquency 


\section{Pendahuluan}

\begin{abstract}
Sekolah merupakan wadah untuk menciptakan manusia yang bermutu dan berpendidikan. Siswa dan siswi berinteraksi di dalamnya menjadikan sekolah sebagai salah satu lingkungan bagi mereka dalam berkembang, bergaul dan belajar. Lingkungan sekolah yang baik akan menjadikan siswa-siswinya menjadi orang yang berguna sehingga banyak sekolah-sekolah yang menyediakan fasilitas yang terbaik untuk memfasilitasi kebutuhan siswanya, salah satunya yaitu menyediakan akses internet dengan mudah agar siswa-siswinya tidak ketinggalan seperti halnya pelajar di kota-kota besar dan negara-negara besar lain.
\end{abstract}

Internet merupakan produk teknologi baru yang terus menerus mengalami perkembangan. Internet merupakan jaringan komputer yang terhubung satu sama yang lain melalui media komunikasi, seperti kabel telepon, serat optik, satelit ataupun gelombang frekuensi. Jaringan ini dapat berukuran kecil seperti Local Area Network (LAN) yang biasa dipakai secara internal di kantor-kantor, bank atau perusahaan atau bisa disebut dengan intranet, dapat juga berukuran superbesar seperti internet (Raharjo, 2002: 59).

Perkembangan internet seakan tiada hentinya seperti halnya aplikasi di dalamnya. Mulai dari aplikasi surat elektronik yang dikenal dengan e-mail, online games, sampai ke jejaring sosial, seperti: twitter, path, instagram, facebook, dan sebagainya. Internet memberikan banyak pengaruh bagi kehidupan manusia, di satu sisi memberikan berbagai kemudahan bagi penggunanya tetapi di sisi lain memberikan dampak negatif seperti individu yang larut dalam mengakses internet, tidak mampu mengontrol penggunaan sehingga berdampak buruk pada pekerjaan, perilaku, hubungan, atau aktivitas penting lainnya.

Larut dalam kesenangan menggunakan game online, mengakses semua hal yang ingin diketahui tanpa perlu susah untuk belajar, mengonsumsi hal negatif melalui tontonan-tontonan yang berbau pornoaksi/ pornografi merupakan sebagian dampak negatif dari penggunaan internet oleh siswa yang masih berada pada usia remaja dan usia berkembang. Siswa yang seharusnya belajar menjadi malas dan hanya mengakses langsung hal yang tidak diketahui, waktu yang harusnya dihabiskan untuk belajar dihabiskan untuk main game online, menonton hal-hal yang berbau porno aksi sehingga banyak siswa-siswi hamil di luar nikah dan terpaksa berhenti bersekolah, tontonan yang berbau kekerasan menjadikan siswa meniru dan menyebabkan kericuhan dan perkelahian di sekolah.

SMA Negeri 2 Tomia merupakan sekolah yang terletak di Kabupaten Wakatobi Pulau Tomia Kecamatan Tomia Timur. Sekolah yang dibangun tahun 2010 ini merupakan sekolah tingkat atas pertama yang ada di Kecamatan Tomia Timur sehingga pembangunannya sangat diperhatikan oleh pemerintah setempat. Walaupun baru dibangun tahun 2010 sekolah ini sudah difasilitasi dengan jaringan wi-fi sehingga siswa-siswanya dapat mengakses internet di sekolah dengan mudah melalui telepon selular yang sudah berbasis android.

Fasilitas yang di peruntukkan untuk membantu dan memermudah siswa dalam belajar sehingga tidak kalah dengan kota-kota besar justru menjadikan siswa malas belajar dan meningkatkan ragam dari kenakalan siswa. Kenakalan yang umumnya hanya terlambat datang ke sekolah, bolos, tidak hadir, berseragam tidak lengkap, mengonsumsi minuman beralkohol, menyontek melalui telepon genggam dengan bahan berasal dari internet, bermain game online saat jam pelajaran, perkelahian, pemerasan/ pemalakan dan hamil di luar nikah yang faktor pemicunya menonton video asusila di internet.

Informasi yang diperoleh dari guru BK di sekolah SMA Negeri 2 Tomia pada observasi awal menyatakan bahwa pemicu terbesar terjadinya kenakalan remaja tidak lain karena tontonantontonan yang menyimpang dari norma yang diperoleh dari internet. Selain itu, banyak pula informasi-informasi palsu yang tersebar di internet menyebabkan siswa menjadi terbawa arus informasi tersebut. Informasi-informasi yang tersebar di kalangan siswa berupa informasi negatif yang melanggar norma. Pada akhirnya siswa ikut-ikutan melakukan perilaku yang menyimpang dari norma.

Willis (2005) menyatakan bahwa kenakalan remaja diartikan sebagai suatu hasil dari proses yang menunjukkan penyimpangan tingkah laku atau pelanggaran terhadap norma yang ada. Kenakalan siswa disebabkan oleh berbagai faktor seperti lingkungan, pribadi, keluarga, dan media sosial. Teknologi internet sebagai media sosial yang menawarkan berbagai kemudahan bagi penggunanya untuk mengakses internet yang tiada batas. Hal-hal yang mungkin mustahil dinikmati dalam dunia nyata menjadi sangat mungkin didapatkan, termasuk hal-hal yang berhubungan dengan kekerasan, seksualitas, penipuan, penculikan dan kenakalan remaja lainnya (Aryani dalam Andrianie, 2006: 2). 
Berdasarkan wawancara awal peneliti dengan guru BK di SMA Negeri 2 Tomia diperoleh bahwa penggunaan internet oleh siswa berpotensi membuat perilaku siswa ke arah yang negatif. Internet sebagai media yang memberikan kemudahan akses informasi secara bebas dilakukan oleh siswa-siswi SMA Negeri 2 Tomia sangat meresahkan guru-guru karena fasilitas yang harusnya dimanfaatkan untuk pembelajaran justru hanya menjadikan perilaku siswa menjadi semakin buruk ke arah negatif.

Berdasarkan uraian latar belakang yang telah diuraikan sebelumnya, peneliti bermaksud melaksanakan sebuah penelitian dengan judul "Pengaruh Penggunaan Internet Terhadap Kenakalan Remaja (Siswa) SMA Negeri 2 Tomia". Tujuan penelitian ini adalah untuk mengetahui apakah ada pengaruh penggunaan negatif internet terhadap kenakalan remaja siswa SMA Negeri 2 Tomia.

\section{Bentuk-bentuk kenakalan remaja}

Kenakalan remaja sebagai sebuah perilaku penyimpangan sosial memiliki bentuk yang bermacam-macam. Berikut dijelaskan bentukbentuk kenakalan oleh beberapa ahli.

1. Gunarsa (2004: 19) menyatakan dari segi hukum kenakalan remaja digolongkan dalam dua kelompok yang berkaitan dengan norma-norma hukum yaitu sebagai berikut:

a. Kenakalan yang bersifat moral dan sosial serta tidak diantar dalam undang-undang sehingga tidak dapat atau sulit digolongkan sebagai pelanggaran hukum.

b. Kenakalan yang bersifat melanggar hukum dengan penyelesaian sesuai dengan undangundang dan hukum yang berlaku sama dengan perbuatan melanggar hukum bila dilakukan orang dewasa.

2. Sunarwiyati (1985) membagi kenakalan remaja ke dalam tiga tingkatan yaitu sebagai berikut:

a. Kenakalan biasa, seperti suka berkelahi, berbohong, begadang, suka keluyuran, buang sampah sembarang, membolos sekolah, pergi dari rumah tanpa pamit.

b. Kenakalan yang menjurus pada pelanggaran dan kejahatan seperti mengendarai mobil tanpa SIM, minum-minuman keras, mencuri, mencopet, berjudi, mengambil barang orang tua tanpa izin.

c. Kenakalan khusus seperti penyalahgunaan narkotika, hubungan seks di luar nikah, pergaulan bebas, pemerkosaan, membunuh, menonton film porno, membaca gambar porno. Kategori di atas yang dijadikan ukuran kenakalan remaja dalam penelitian.

3. Sarwono (2006: 256) membagi kenakalan remaja menjadi empat bentuk yaitu sebagai berikut:

a. Kenakalan yang menimbulkan korban fisik pada orang lain: perkelahian, perkosaan, perampokan, pembunuhan, dan lain-lain.

b. Kenakalan yang menimbulkan korban materi: perusakan, pencurian, pencopetan, pemerasan, dan lain-lain.

c. Kenakalan sosial yang tidak menimbulkan korban di pihak orang lain: pelacuran, penyalahgunaan obat dan hubungan seks bebas.

d. Kenakalan yang melawan status, misalnya mengingkari status anak sebagai pelajar dengan cara membolos, minggat dari rumah, dan membantah perintah.

Jenis-jenis penggunaan negatif internet

Haryono (dalam Hassan, 2012: 4) menyatakan bahwa jenis-jenis penggunaan negatif internet di kalangan pelajar yaitu sebagai berikut:

1. Pornografi

Internet sangat identik dengan yang namanya pornografi. Dengan adanya kemampuan penyampai informasi yang dimiliki internet, pornografipun merajalela. Hal-hal ini sering terjadi di kalangan pelajar yang berawal dari penasaran sampai mereka berani untuk membuka situs pornografi dan melihatnya. Hal ini sangat disayangkan oleh dunia pendidikan karena melihat anak yang masih di bawah bimbingan orang tua melihat yang tidak sepatutnya

2. Plagiat

Mahasiswa yang malas mengerjakan tugasnya sendiri sering melakukan pelagiat yaitu sering mengerjakan tugas dengan cara mencontek dan pada saat ini dunia teknologi semakin canggih maka mereka semakin mudah untuk mencari semakin mudah untuk mencari jawaban ketikan sedang ujian sekolah.

\section{Game online}

Game online adalah sebuah permainan (games) yang dimainkan dalam suatu jaringan LAN maupun internet. Games saat ini tidak seperti game terdahulu, jika dahulu game hanya bisa dimainkan maksimal dimainkan dua orang, sekarang dengan kemajuan teknologi terutama jaringan internet game bisa dimainkan 100 orang lebih sekaligus dalam waktu yang bersamaan. Game online juga membawa dampak yang besar terutama pada perkembangan anak maupun jiwa 
seseorang. Walaupun kita dapat bersosialisasi dengan pemain lainnya game online kerap membuat pemainnya merupakan kehiduan sosial dalam kehidupan yang sebenarnya, terutama di kalangan pelajar yang sering menggunakan game online sebagai hiburan untuk menghilangkan kejenuhan di saat banyak tugas sekolah.

Penyebab penggunaan negatif internet

Sarwono (2012) menyatakan bahwa penyebab dari penggunaan negatif internet antara lain sebagai berikut:

1. Kurangnya pengawasan orang tua

Orang tua adalah orang pertama yang harus selalu memerhatikan dan membimbing anaknya baik di rumah, sekolah maupun di luar. Namun orang tua yang selalu sibuk dengan pekerjaannya, menyebabkan komunikasinya tidak baik dan tidak ada keterbukaan. Orang tua yang tidak memiliki pengetahuan tentang internet, dan terlalu memercayai anaknya menjadikan anak merasa bebas untuk melakukan segala hal melalui internet.

2. Kurangnya kesadaran diri

Kurangnya kesadaran diri dalam memilih informasi dan menggunakan informasi yang diperoleh melalui internet dapat menyebabkan diri terjerumus dalam kejahatan atau situasi yang buruk. Sehingga yang akan diperoleh hanyalah penyesalan yang tiada berarti.

3. Pengaruh teman sebaya

Teman sebaya merupakan salah satu dunia anak yang membantu membentuk karakter serta kepribadian anak. Teman yang baik akan membetuk karakter yang baik bagi anak lainnya, sebaliknya teman yang tidak baik akan menjerumuskan anak pada pergaulan yang buruk seperti melakukan perkelahian atau kekerasan.

4. Pergaulan bebas

Pergaulan bebas merupakan istilah bagi anak yang memiliki pergaualan tidak terkontrol atau bebas melakukan apa saja tanpa peduli baik dan buruknya. Terjerumus pada pergaulan yang seperti ini akan menjadikan anak terjerumus dalam lembah hitam. Apapun yang dilakukan teman bergaulnya akan menjadi hal yang sama yang dilakukan oleh anak seperti seks bebas tanpa takut akan bahayanya.

5. Fasilitas yang memadai

Fasilitas yang memadai merupakan salah satu penyebab anak menyalahgunakan internet. Karena dengan fasilitas yang ada anak bisa mengakses apa saja yang dia mau seperti tontonan kekerasan dan pornografi.

Dampak internet pada siswa

Hardjito (2001: 10) menyatakan bahwa dalam penggunaan internet pada siswa dapat menimbulkan dampak positif dan dampak negatif yaitu sebagai berikut.

1. Dampak positif internet

Bagi para siswa di sekolah maupun masyarakat umum internet antara lain sebagai berikut:

a. Sarana komunikasi yang murah dan mudah, bahkan untuk berkomunikasi langsung (chating) lebih murah daripada menggunakan telepon seluler.

b. Dapat berhubungan langsung dengan para pakar/ ahli misalnya: konsultasi kesehatan, psikologi, konsultasi ilmu pengetahuan, konsultasi hukum dan lain-lain meski dengan jarak yang sangat jauh dan perlu waktu beberapa hari bila kita berkeinginan untuk menemui pakar tersebut.

c. Dapat mengetahui isi buku, walau buku itu belum kita beli, kita dapat ngedonwload-nya secara gratis.

d. Bisa mendapatkan teman baru dari mana saja, sahabat bahkan ketemu saudara yang berada jauh dan lama tidak ketemu, bahkan mungkin bias mendapatkan jodoh.

e. Dapat bertukar informasi dan ilmu pengetahuan, kapan saja, dimana saja dengan siapa saja, menambah wawasan, dan ilmu pengetahuan.

f. Sebagai sarana untuk belajar dan berdiskusi bagi para siswa yang sedang belajar baik di rumah atau di sekolah.

g. Sumber mencari pengetahuan .

h. Internet untuk media komunikasi.

i. Internet bisa dijadiakn saling bertukar data.

2. Dampak negatif internet

Haryono (2006: 35) menyatakan bahwa dampak buruk internet bila tidak dibimbing dan diarahkan dengan baik antara lain:

a. Obral-obrol dengan kurang sopan dan atau tidak senonoh. Ini perlu dicegah jangan sampai para siswa atau siapa pun juga obralobrol tidak senonoh yang menjurus ke hal yang berbau porno dengan siapa saja baik wanita maupun pria.

b. Terkena penyakit rematik dan otot pegalpegal. Orang yang sedang bermain internet 
terkadang lupa waktu, duduk dengan posisi yang menetap di depan komputer atau laptop, sudah dapat maklum selain dampak radiasi. Juga gerak badan yang kurang aktif akibatnya penyakit pegal dan rematik gampang menyerang.

c. Terkena virus. Ternyata internet adalah media yang digunakan virus untuk menyebar.

d. Lupa waktu. Ini sering terjadi karena asyknya berinternet ria sampai lupa waktu, waktu makan, beribadah, sekolah, dan lain-lain.

e. Bahaya penipuan. Waspada terhadap penipuan di internet. Kita sering berkomunikasi dengan orang yang belum kenal dan belum jelas identitasnya waspada terhadap ajakan bujukan dan penawaran bisnis dengan orang yang belum jelas.

f. Konten dewasa. Konten seperti ini biasanya banyak digunakan oleh pemilik situs demi mendongkrak penjualan situs.

g. Judi. Para penjudi tidak harus ke tempat judi untuk melakukan kegiatan dan keinginannya yang perlu dilakukan hanyalah mengunjungi situs-situs perjudian.

Selanjutnya Darmawan (2008: 17) menjelaskan bahwa penggunaan negatif internet memiliki dampak positif pada siswa yang sering menggunakan internet yaitu:

a. Internet memberikan segala informasi pendidikan yang sangat banyak dan luas, hal ini tentu sangat berguna bagi para siswa dalam menunjang proses belajar mereka.

b. Internet membuat proses belajar menjadi lebih cepat, hal ini dikarenakan internet sangat mudah digunakan dan didukung oleh banyaknya search engine (mesin pencari) seperti Google untuk mencari informasi. Siswa tinggal membuka mesin pencari, memasukan kata kunci yang di inginkan, lalu muncullah segalah informasi yang dibutuhkan.

c. Dengan banyaknya informasi yang tersedia di internet dan kemudahan untuk mendapatkannya siswa cenderung untuk terus belajar dan mencari segala macam info di dunia maya ini. Hal tersebut adalah salah satu pengaruh internet terhadap prestasi belajar siswa dari segi positif.

d. Tak seperti buku, internet menyuguhkan informasi dengan cara yang lebih menarik. Misalnya, bila ada gambar pada suatu artikel, gambar tersebut kadang bergerak (animasi), hal ini tentu lebih menarik dan membuat otak siswa tidak jenuh. e. Tak hanya soal pendidikan, internet juga menyuguhkan jejaring sosial yang berguna untuk melatih siswa agar lebih baik dalam bersosialisasi, baik dengan orang-orang yang sudah dikenal maupun dengan orang asing.

\section{Metode Penelitian}

Penelitian ini dilaksanakan di kelas XI IPS SMA Negeri 2 Tomia Kabupaten Wakatobi yang tersebar pada 4 kelas paralel tahun akademik 2016/ 2017. Waktu penelitian dilaksanakan pada bulan Maret sampai bulan April tahun 2017.

Jenis penelitian ini merupakan penelitian expost facto. Penelitian expost facto atau sering disebut juga sebagai kasual komparatif, merupakan penelitian yang berusaha mencari informasi tentang hubungan sebab akibat dari suatu peristiwa. Menurut Kerlinger (2013: 119) penelitian kausal komparatif atau expost facto adalah penyelidikan empiris yang sistematis dimana ilmuwan tidak mengendalikan variabel bebas secara langsung karena eksistensi dari variabel tersebut telah terjadi atau karena variabel tersebut pada dasarnya tidak dapat dimanipulasi.

Rancangan penelitian ini dapat digambarkan sebagai berikut:

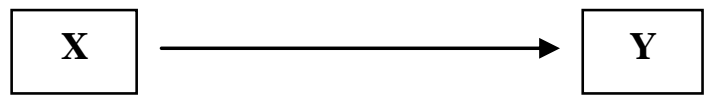

\section{Bagan 1. Desain Penelitian}

Penarikan sampel penelitian dilakukan dengan menggunakan teknik purposive sampling. Hal ini mengacu pada pendapat Sugiyono (2012: 126) menjelaskan bahwa purposive sampling adalah teknik pengambilan sampel didasarkan atas pertimbangan tertentu. Dalam penelitian ini, peneliti hanya mengambil sampel yang memiliki ciri-ciri atau karakteristik sebagai siswa berkenakalan remaja pada penggunaan internet. Penggunaan internet yang dimaksud adalah seperti menonton video porno di sekolah, melakukan plagiasi (menyontek) dan siswa yang terlibat atau kecanduan game online. Setelah melalui pertimbangan tersebut, maka peneliti menetapkan sebanyak 32 orang sebagai sampel dalam penelitian ini, yaitu siswa yang tergolong dalam kenakalan remaja pada penggunaan internet.

Teknik pengumpulan data yang digunakan dalam penelitian ini adalah angket dan dokumentasi. Sebelum digunakan sebagai instrument penelitian, angket terlebih dahulu dilakukan uji coba instrument. Uji coba instrument penelitian diuji 
cobakan kepada 50 responden di luar sampel penelitian sebelum penelitian dilakukan. Instrumen yang diuji coba merupakan angket dari penggunaan internet dan angket dari kenakalan remaja. Untuk menguji validitas butir angket yang telah dibuat digunakan rumus product moment dengan rumus:

$$
r_{x y}=\frac{N \sum \mathrm{XY}-\left(\sum \mathrm{X}\right)\left(\sum \mathrm{Y}\right)}{\sqrt{\left\{N \sum X^{2}-\left(\sum X^{2}\right)\right\}}\left\{N \sum Y^{2}-\left(\sum Y^{2}\right)\right\}}
$$

Keterangan:

$\mathrm{r}_{x y} \quad=$ Koefisiean korelasi product moment

$\mathrm{N} \quad=$ Banyaknya responden

$\sum Y=$ Jumlah skor seluruh item

$\sum X=$ Jumlah skor masing- masing item

$\sum X Y=$ Jumlah skor selurh item

$\sum Y^{2} \quad=$ Kuadrat dari skor total

$\sum X^{2}=$ Kuadrat dijumlah skor tiap item.

Setelah selesai menghitung validitas tiap butir angket, dilanjutkan dengan menghitung realibilitas instrument dilakukan menggunakan rumus Cronbach Alpha.

Analisis data dalam penelitian ini menggunakan teknik analisis statistik deskriptif dan analisis inferensial. Analisis deskriptif menggambarkan masing-masing variabel dengan menghitung nilai minimum, nilai maksimum, mean, standar deviasi, dan varian. Sedangkan analisis inferensial menggunakan analisis KolmogorovSmirnov dengan bantuan SPSS Version 16.0. Selanjutnya, untuk mencari makna hubungan variabel $\mathrm{X}$ dan $\mathrm{Y}$ maka hasil kolerasi Product moment di uji dengan uji signifikan dengan rumus:

$$
\mathrm{t}=\frac{\mathrm{r}}{\sqrt{\frac{1-\mathrm{r}^{2}}{\mathrm{n}-2}}}
$$

(Sugiyono, 20015: 230)

Keterangan:

$\mathrm{t}_{\text {hitung }}=$ Nilai signifikasi

$\mathrm{r} \quad=$ Nilai

$\mathrm{N}=$ Jumlah sampel

Distribusi (Tabel t) untuk $a=0,05$ dan derajat bebas $(\mathrm{db})=\mathrm{N}-2$ dengan kaidah keputusan: Jika $t_{\text {hitung }}>t_{\text {tabel }}$ berarti signifikan, sebaliknya Jika $t_{\text {hitung }}<t_{\text {tabel }}$ berarti tidak signifikan

\section{Hasil Penelitian dan Pembahasan Hasil Penelitian}

Analisis data merupakan hal yang penting dalam penelitian. Dalam bagian ini dikemukakan deskripsi hasil penelitian berdasarkan hasil instrument penelitian penggunaan internet terhadap kenakalan remaja (Siswa) SMA Negeri 2 Tomia. Dengan menggunakan Analisis data dalam penelitian ini menggunakan teknik analisis statistik deskriptif dan analisis inferensial dengan bantuan Spss Version 16.0.

1. Deskriptif penggunaan internet

Data penggunaan internet diperoleh dengan menggunakan data dari angket yang diberikan kepada 32 orang siswa yang mengisi angket dengan skor minimum 177, skor maksimum 211, rata-rata (mean) 201.72, simpangan baku (standar deviation) 9.274, varians 86.105. Selanjutnya untuk mengetahui rentang skor dan jumlah responden/ siswa yang masuk dalam kategori rendah sekali, rendah, tinggi, tinggi sekali, maka dibuat distribusi frekuensi skor variabel penggunaan negatif interenet yang dapat dilihat pada tabel tabel berikut:

Tabel 1

Distribusi Frekuens Penggunaan Internet

\begin{tabular}{|c|c|c|c|}
\hline Interval & Kategori & $\boldsymbol{f}$ & $\mathbf{\%}$ \\
\hline $\mathrm{X} \geq 216$ & Tinggi Sekali & 1 & 3.13 \\
\hline $206 \leq \mathrm{X}<216$ & Tinggi & 11 & 34.38 \\
\hline $197 \leq \mathrm{X}<206$ & Sedang & 13 & 40.63 \\
\hline $188 \leq \mathrm{X}<197$ & Rendah & 4 & 12.50 \\
\hline $\mathrm{X}<188$ & Rendah Sekali & 3 & 9.38 \\
\hline \multicolumn{2}{|c|}{ Jumlah } & $\mathbf{3 2}$ & $\mathbf{1 0 0}$ \\
\hline
\end{tabular}

Berdasarkan data pada tabel di atas maka dibuat grafik distribusi data penggunaan internet sebagai berikut:

\section{Grafik 1}

\section{Distribusi Data Penggunaan Internet}

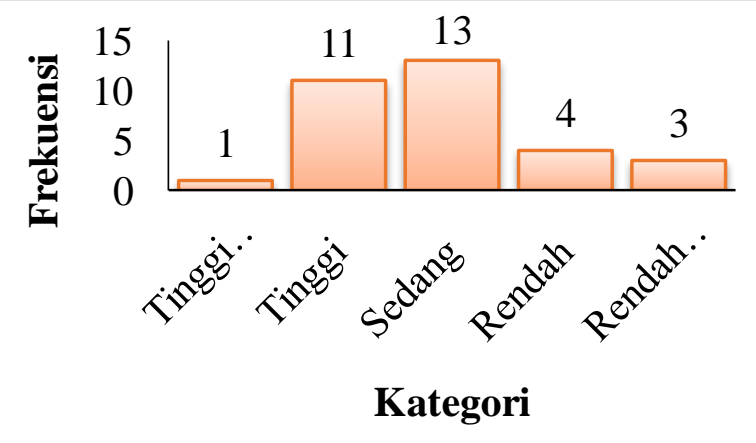


Hasil analisis terhadap penggunaan internet siswa SMA Negeri 2 Tomia yang dilaksanakan pada 32 siswa yang menjadi sampel penelitian menunjukan bahwa penggunaan internet siswa yang berkategori tinggi sekali 1 siswa $(3,13 \%)$, kategori tinggi 11 siswa $(34,38 \%)$, kategori sedang 13 siswa $(40,53 \%)$, kategori rendah 4 siswa $(12,50 \%)$, kategori rendah sekali 3 siswa $(9,38 \%)$.

2. Deskriptif kenakalan remaja

Data kenakalan remaja dengan menggunakan angket yang terdiri dari 32 orang siswa yang mengisi angket dengan skor minimum 187, skor maksimum 229, rata-rata (mean) 209.91, simpangan baku (standar deviation) 115.701, varians 115.701. Selanjutnya untuk mengetahui rentang skor dan jumlah responden/ siswa yang masuk dalam kategori rendah sekali, rendah, tinggi, tinggi sekali maka dibuat distribusi frekuensi skor variabel kenakalan remaja yang dapat dilihat pada tabel berikut:

Tabel 2

Distribusi Frekuensi Skor Variabel Kenakalan Remaja

\begin{tabular}{|c|c|c|c|}
\hline Interval & Kategori & $\boldsymbol{f}$ & $\boldsymbol{\%}$ \\
\hline $\mathrm{Y} \geq 226$ & Tinggi Sekali & 1 & 3.13 \\
\hline $215 \leq \mathrm{Y}<226$ & Tinggi & 10 & 31.25 \\
\hline $205 \leq \mathrm{Y}<215$ & Sedang & 11 & 34.38 \\
\hline $194 \leq \mathrm{Y}<205$ & Rendah & 7 & 21.88 \\
\hline $\mathrm{Y}<194$ & Rendah Sekali & 3 & 9.38 \\
\hline \multicolumn{2}{|c|}{ Jumlah } & 32 & 100 \\
\hline
\end{tabular}

Berdasarkan tabel di atas maka dibuat grafik distribusi data kenakalan remaja sebagai berikut:

Grafik 2

Distribusi Data Kenakalan Remaja.

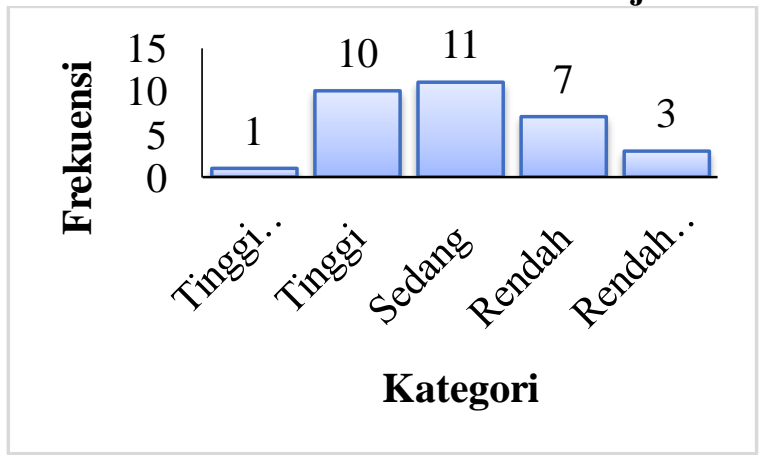

Berdasarkan tabel dan grafik tersebut dapat dilihat bahwa penggunaan internet siswa SMA Negeri 2 Tomia yang dilaksanakan pada 32 siswa yang menjadi sampel penelitian menunjukan bahwa penggunaan internet siswa yang berkategori tinggi sekali 1 siswa $(3,13 \%)$, kategori tinggi 10 siswa $(31,25 \%)$, kategori sedang 11 siswa $(34,38 \%)$, kategori rendah 7 siswa $(21,88 \%)$, kategori rendah sekali 3 siswa $(9,38 \%)$.

3. Pengujian hipotesis

Untuk mengetahui pengaruh penggunaan negatif internet terhadap kenakalan remaja digunakan rumus t-test. Adapun langkah yang ditempuh sebelum melaksanakan analisis $t$-test adalah uji normalitas data sebelum dan sesudah pemberian layanan informasi.

a. Uji Normalitas

Pengujian normalitas data dilakukan dengan menggunakan statistik non parametrik Kolmogorov-Smirnov. Berdasarkan hasil analisis dengan SPSS diperoleh nilai uji normalitas pada residual data diperoleh nilai Asymp. Sig. (2-tailed) sebesar 0,997 $\geq \alpha$ $(0,05)$, maka dapat disimpulkan bahwa residual data berdistribusi normal.

b. Uji t ( $t$-test)

Hipotesis yang diajukan adalah ada pengaruh yang signifikan penggunaan internet terhadap kenakalan remaja siswa di SMA Negeri 2 Tomia. Dari hasil analisis korelasi dengan menggunakan SPSS diperoleh $\mathrm{r}_{\mathrm{xy}}=$ 0,573 (kategori sedang), hal ini mengindikasikan bahwa ada hubungan penggunaan internet dengan kenakalan remaja siswa di SMA Negeri 2 Tomia.

Besarnya kontribusi penggunaan internet terhadap kenakalan remaja ditunjukkan dengan koefisien determinasi sebesar 32,8\% yang berarti bahwa $32,8 \%$ variansi perubahan yang terjadi pada variabel kenakalan remaja siswa di SMA Negeri 2 Tomia Kabupaten Wakatobi dijelaskan oleh variabel penggunaan internet siswa, dan sisanya sebesar $67,2 \%$ dijelaskan oleh variabelvariabel lain.

Selanjutnya dilakukan uji signifikansi dengan uji-t untuk menguji hipotesis penelitian. Berdasarkan hasil analisis yang terdapat pada lampiran, diperoleh nilai $t_{\text {hitung }}$ sebesar 3,830 dengan Sig. $=0,001<\alpha(0,05)$, sehingga hipotesis $\mathrm{H}_{0}$ 
ditolak. Artinya ada pengaruh yang signifikan antara penggunaan internet siswa terhadap kenakalan remaja siswa di SMA Negeri 2 Tomia Kabupaten Wakatobi.

\section{Pembahasan}

Berdasarkan hasil analisis pengujian hipotesis antara penggunaan internet dengan kenakalan remaja siswa diperoleh koefisien korelasi pada kategori sedang. Nilai korelasi tersebut positif sehingga dapat dikatakan bahwa jika penggunaan internet siswa tinggi, maka kenakalan remaja siswa akan tinggi pula. Hal ini sesuai dengan persamaan regresi linear sederhana antara penggunaan internet terhadap kenakalan remaja yang mengandung makna bahwa telah ada potensi kenakalan remaja siswa sebesar 75,842 tanpa dipengaruhi oleh variabel penggunaan internet. Setiap kenaikan satu satuan skor variabel penggunaan internet maka akan diikuti dengan peningkatan kenakalan remaja siswa sebesar 0,665 .

Sejalan dengan penelitian yang dilakukan Rahardiyan (2011) bahwa dari beberapa dampak negatif dari intensitas pemanfaatan internet yang dibahas, dampak negatif yang dominan memengaruhi siswa adalah dampak bahwa internet bisa menurunkan pola interaksi siswa dalam lingkungan sosialnya. Dampak negatif yang lain seperti misalnya sikap sosial, perkenalan kepada dunia kejahatan, maupun kecanduan terhadap halhal negatif tidak sempat dialami oleh para siswa yang intensitas pemanfaatan internetnya tergolong berat sekalipun.

Berdasarkan uraian yang telah dikemukakan di atas dan hasil analisis pengujian hipotesis, maka hipotesis yang menyatakan ada pengaruh yang signifikan antara penggunaan internet siswa terhadap kenakalan remaja siswa di SMA Negeri 2 Tomia Kabupaten Wakatobi secara empiris telah terbukti kebenarannya. Oleh sebab itu, dapat dikatakan bahwa semakin tinggi penggunaan internet siswa, maka akan semakin tinggi pula kenakalan remaja siswa tersebut. Besarnya kontribusi variabel penggunaan internet siswa terhadap kenakalan remaja siswa di SMA Negeri 2 Tomia Kabupaten Wakatobi adalah sebesar 32,8\%.

Pengaruh yang dihasilkan dari internet menurut penelitian yang dilakukan oleh Lina Aprilia (2014) antara lain: (1) menjadikan siswa malas belajar ataupun beraktivitas lainnya yang lebih menguntungkan daripada hanya membuka dan mengakses Internet, (2) gaya hidup yang tidak sesuai dengan pola kehidupan di dalam lingkungan yang mereka tempati, dalam hal ini model pakaian yang kurang sopan sebab memerlihatkan auratnya, (3) berani untuk bertengkar disebabkan seringnya bermain game online yang didalamnya terdapat adegan-adegan berbahaya, kekerasan, peperangan yang menyebabkan siswa untuk terpengaruh mengaplikasikannya dalam kehidupan apabila merasa dirinya terganggu, (4) membolos sekolah dikarenakan siswa lebih merasa asik atau nyaman ketika berada di warnet, dari pada belajar di sekolah.

\section{Kesimpulan dan Saran Kesimpulan}

Berdasarkan hasil analisis data dan pembahasan maka kesimpulan penelitian ini adalah ada pengaruh yang signifikan penggunaan internet siswa terhadap kenakalan remaja siswa di SMA Negeri 2 Tomia Kabupaten Wakatobi. Hal ini menunjukkan bahwa semakin tinggi penggunaan negatif internet, maka semakin tinggi pula kenakalan remaja siswa di SMA Negeri 2 Tomia Kabupaten Wakatobi. Besarnya kontribusi penggunaan internet terhadap kenakalan remaja siswa di SMA Negeri 2 Tomia adalah sebesar $32,8 \%$.

\section{Saran}

Berdasarkan hasil penelitian di atas, maka saran-saran yang dapat dikemukakan adalah sebagai berikut:

1. Secara statisitik, ada pengaruh yang signifikan penggunaan internet terhadap kenakalan remaja siswa di SMA Negeri 2 Tomia Kabupaten Wakatobi. Untuk itu, perlu adanya sosialisasi penggunaan internet secara sehat oleh pihak sekolah.

2. Hasil penelitian menunjukkan bahwa semakin tinggi penggunaan internet ke arah negatif maka semakin tinggi pula kenakalan remaja. Perlu ada perhatian khusus orang tua dalam mengawasi anaknya, dalam hal ini terkait penggunaan telepon genggam. Orang tua harus lebih berhatihati memberikan kontrol penuh anak menggunakan telepon genggam, karena bisa saja anak menggunakannya ke arah yang negatif.

\section{Daftar Pustaka}

Raharjo, Agus. (2002). Cybercrime Pemahaman dan Upaya Pencegahan Kejahatan Berteknologi. Bandung: Penerbit PT. Citra Aditya Bakti.

Andrianie, H. (2006). Pergaulan Bebas di Kalangan Remaja yang Mengkhawatirkan. Jakarta: Remaja Rosdakarya. 
Darmawan, Rudi. (2008). Modul Teknologi Informasi dan Komunikasi. Solo: Hayati.

Gunarsa, Singgih. (2004). Psikologi Perkembangan Anak dan Remaja. Jakarta: BPK Gunung Mulia.

Haryono, H. (2012). Mendayagunakan Internet, Edisis Revisi. Surabaya: Hi-Fest Publishing.

Haryono, H (2006). Mendayagunakan Internet. Surabaya: Hi-Fest Publishing.

Hardjito. (2001). Pola Hubungan Faktor-Faktor Yang Memengaruhi Pemanfaatan Internet: Studi Survey Motif Pemanfaatan Internet Siswa SMU dan SMK DKI Jakarta: Program Pasca Sarjana Universitas Indonesia.

Kerlinger. (2013). Metodologi Penelitian Pendidikan. Depok: PT. Raja Grafindo Persada.

Sunarwiyatin. (1985). Pengukuran Sikap Masyarakat terhadap Kenakalan Remaja. Jakarta, laporan penelitian, UI.

Sarwono, Sarlito Wirawan. (2006). Psikologi Remaja. Jakarta: PT. Raja Grafindo Persada.

Sarwono, Sarlito Wirawan. (2006). Internet Untuk Pembelajaran. Erlangga. Pustaka Manggala: Surakarta.

Sugiyono. (2015). Metode Penelitian Kuantitatif Kualitatif $R \& B$. Bandung: Aflabeta.

Willis, Sofyan S. (2005). Remaja \& Masalahnya: Mengupas Berbagai Bentuk Kenakalan Remaja, Narkoba, Free Sex dan Pemecahannya. Bandung: Penerbit CV. Alfabeta Bandung. 
Jurnal BENING Volume 4 Nomor 1 Januari 2020

26 | Asniati, Sudarmi Suud B, Jahada 